\title{
Germination and cytological aspects of Dolichos lablab L. exposed to gamma radiation
}

\author{
G. Kumar and Swati Keserwani ${ }^{1}$ \\ Department of Botany, Laboratory of Plant Genetics, University of Allahabad, 211002, India \\ ${ }^{1}$ Author for correspondence: (swatikeserwani2@gmail.com) \\ Received June 29, 2017; accepted August 30, 2017
}

\begin{abstract}
The present study aims to determine the impact of gamma radiation on the germination $\%$ and mitotic indices in three varieties of Dolichos lablab L. viz. Arkajay, Swarna uthkrishit and RP-08-31, at different doses of gamma rays i.e. 100, 200, 300 , 400 and $500 \mathrm{~Gy}$. Through the acquisition of the following experiment, an attempt to screen out the superior variety among the three selected varieties was done for Dolichos lablab. Among the three varieties studied, Arkajay showed the highest germination \% and active mitotic index (AMI). A significant decline in AMI and increment in total abnormality percentage (TAB\%) was observed with the increase in gamma rays from lower to higher doses. TAB\% was induced due to the ionizing radiation. Stickiness, precocious movement, laggard and unorientation were found as preponderant chromosomal abnormalies. However, stickiness was the major abnormality at both metaphase and anaphase stages of cell division. In the present study, variety Arkajay emerged as the best variety based on the fact that it showed highest germination percentage and AMI among all of the three varieties selected.
\end{abstract}

KEYWORDS: Active Mitotic Index (AMI), Dolichos lablab, Gamma rays, Total abnormality percentage (TAB\%)

Mutagenic source for creating genetic variation is the gamma radiation. Gamma rays are the electro- magnetic ionizing radiations of high penetration frequency $\left(\geq 10^{19}\right.$ $\mathrm{Hz}$ ) that are used as physical mutagen. Low proportion of gamma radiations is present naturally through solar penetration. Prior to use of gamma rays for mutagenic study, its dose optimization and screening out variation has been always occurred in the wild via spontaneous incidence, that is of course a rare phenomenon. However, the resulting variation provides the raw material for natural selection and is also a driving force in evolution (Oladosu et al. 2016). Introducing artificial mutation through induced mutagenesis has evolved and has been rigorously worked upon by breeders and researchers across the globe for introducing genetic variation. Science of induced mutation has become the embodiment of plant breeding and it has flourished all over the world for improving agronomic traits of various economically important plants. The selection of beneficial dose for the outcome of positive results is critically essential. Since, after exposure the level of incorporation of radionuclide in the cells has a several manifold deleterious effect due to atomic decay (Grodsinsky et al. 2001).

Research on the basic interaction of ionizing radiation (gamma rays) with biological systems has contributed to human society through applications in medicine, agriculture, pharmaceutical uses, and other technological processes (Marcu et al. 2013). The biological effect of gamma-rays is based on the interaction with atoms or molecules in the cell, particularly water, to produce free radicals. This indirect effect of gamma rays is important in vegetative cells, the cytoplasm of which contains about 80\% water (Kovács and Keresztes 2002).

Mitotic study issues the firsthand information for insights to cellular level. It is one of the oldest, simplest and least expensive methods for studying the induction of chromosomal aberrations utilizes plant root tips as experimental material (Kihlman 1975).

Mitotic index study is a cytogenetic test critical for examining genotoxic effects, characterize proliferating cells and to identify materials that inhibit or induce mitotic progression (Eroglu et al. 2007).

Genetic variability has been created in various crops via adopting mutagenic tools and possibly this could assist in providing overwhelming results qualitatively and quantitatively. Previous works aimed at mitotic inception are in Chrysanthemum carinatum (Verma and Chandel 1994), Allium cepa L. (Ahirwar 2013) and Crotalaria juncea (Kumar and Dwivedi 2014). Singh and Datta (2010) have recently shown that low dose of gamma irradiation could be potentially exploited for improving plant vigor and grain productivity.

Dolichos lablab L. (Fabaceae), is an important leguminous plant since it contains high amount of protein. Chromosome constitution compiles $2 n=22$ chromosomes in a diploid cell. The plant is also used as antiinflammatory, aphrodisiac, antispasmodic, antidiabetic, febrifuge and for flatulent, bilious, stomachic disorders (Bhogireddy et al. 2013). Leaves and flowers show antibacterial activity (Priya and Jennifer 2014). The objective of the present research work was to assess the effect of gamma rays on seed germination in three varieties of Dolichos lablab L. and also focus on evaluating the influence of the radiation on the chromosomes of this plant through monitoring the effect of gamma rays on Active Mitotic Index (AMI) and percent frequency of chromosomal abnormality i.e. TAB\%. 


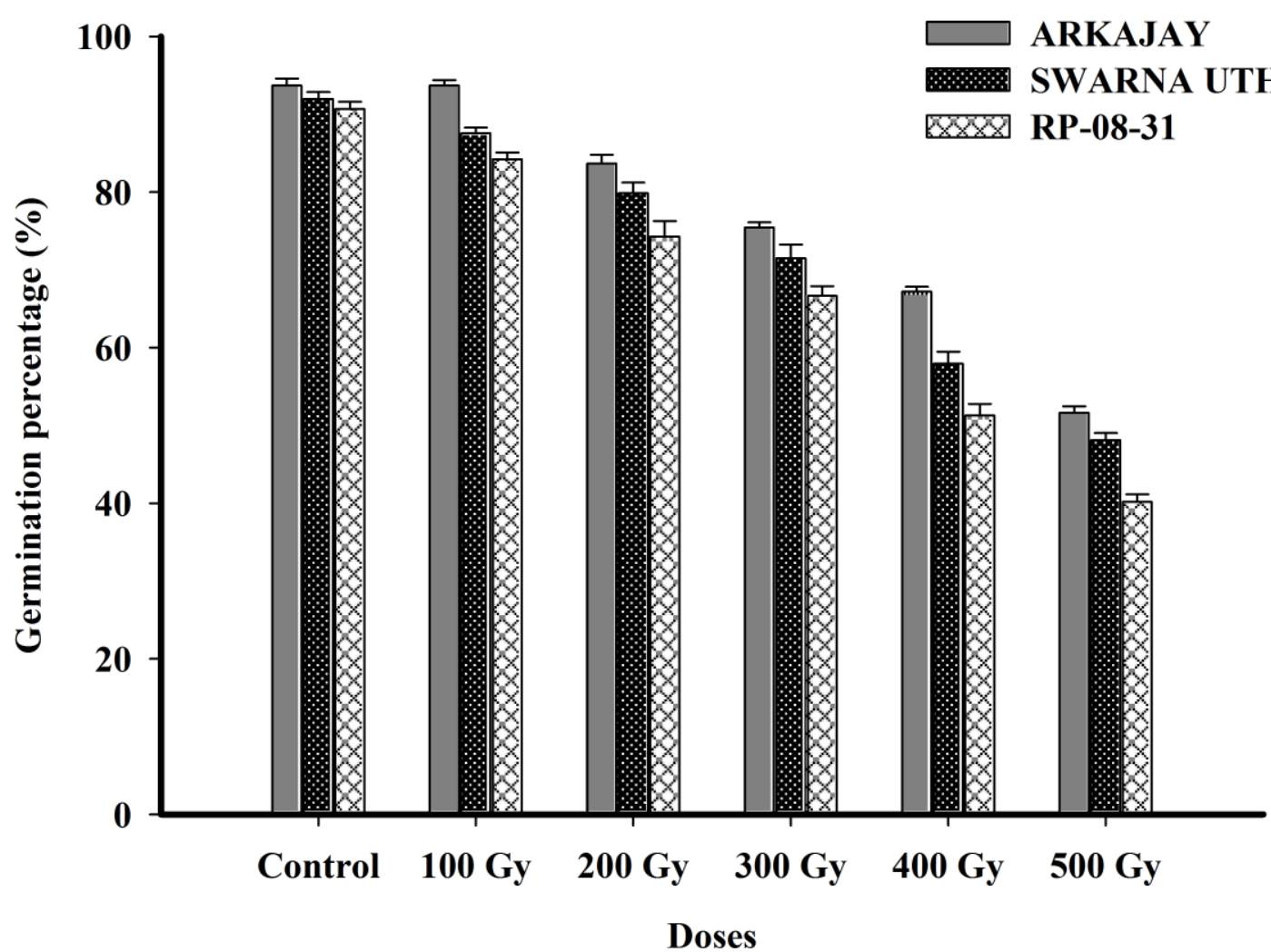

Fig. 1. Comparative account of germination percentage affected by gamma irradiation in three varieries of Dolichos $l a b a b \mathrm{~L}$.

\section{Materials AND Methods}

Fresh seeds of Dolichos lablab L. var. Arka Jay were procured from Indian Institute of Horticultural Research, (IIHR) Bangalore. The other plant variety i.e. Swarna uthkrishit and RP-08-31 were procured from Indian Council of Agricultural Research (ICAR), Varanasi. For gamma irradiation treatment, seeds were irradiated with increasing dose viz. 100 Gy, 200 Gy, 300 Gy, 400 Gy and $500 \mathrm{~Gy}$. Irradiation of seeds was performed at National Bureau of Research Institute (NBRI), Lucknow. The radioactive SUBSTANCE Cobalt 60 was the source of gamma radiation.

Irradiated seeds were allowed for germination in seed germinator in water soaked filter papers. After germination, the irradiated roots alongwith the control (that was unradiated), were fixed in carnoy's fixative (1:3, Glacial Acetic Acid and Absolute alcohol) in labelled plastic bottles. The roots were preserved in $90 \%$ alcohol.

Slides were prepared for cytological study. First of all, roots were hydrolysed in $1 \mathrm{~N} \mathrm{HCl}$ on water bath. After careful washing with distilled water, the roots were blotted on blotting paper, followed by staining in $2 \%$ acetocarmine. After staining, the darker stained root tips were excised and squashed in $2 \%$ acetocarmine mount. Slides were observed at $40 \mathrm{X}$ resolution and photographs were captured through PCTV software in Nikon phase contrast microscope. Five slides were prepared for each dose and several microscopic views from each slide was recorded for scoring of Active Mitotic Index (AMI\%) and Total Abnormality Percentage (TAB\%).

Statistical assessment The data were analyzed by the SPSS 16.0 software. There were three replicates of plant varieties for each treatment and one independent variation. A one way analysis of variance (ANOVA) and Duncan's multiple range test (DMRT, $P<0.05$ ) were performed for mean separation and the graph was plotted using Sigma Plot 10.0 software. Actual mean and standard error were calculated.

\section{RESULTS}

Influence on germination of the seeds Somatic chromosome study of gamma irradiation on the germination of the seeds is important for detecting induction of various chromosomal anomalies. Fig. 1 indicates clearly the comparative study on germination of the seeds in three varieties of $D$. lablab exposed to gamma irradiation. Percentage of seed germination exposed by the gamma irradiation at 100 and 200 Gys were closed to the control set. It started decreasing after the gamma irradiation exposures by 300 and 500 Gy doses, respectively; a marked decline was observed. Fig. 1 comprised the order of the superiority among the three varieties on the criteria of seed germination on. It has been 
Table 1. Comparative account of Metaphasic and Anaphasic abnormalities induced by Gamma irradiation in three varieties of Dolichos lablab L.

\begin{tabular}{|c|c|c|c|c|c|c|c|c|c|c|c|c|c|c|}
\hline \multirow[t]{2}{*}{ Treatment } & \multirow[t]{2}{*}{$\begin{array}{c}\text { Plant } \\
\text { varieties }\end{array}$} & \multirow[t]{2}{*}{ Doses } & \multirow{2}{*}{$\begin{array}{c}\text { AMI } \\
\text { (Mean } \\
\pm \text { S.E.) }\end{array}$} & \multicolumn{4}{|c|}{$\begin{array}{l}\text { Metaphasic Abnormalities } \\
\quad(\text { Mean } \pm \text { S. E.) }\end{array}$} & \multicolumn{6}{|c|}{$\begin{array}{l}\text { Anaphasic Abnormalities } \\
\text { (Mean } \pm \text { S.E.) }\end{array}$} & \multirow[t]{2}{*}{$\begin{array}{l}\mathrm{Tab} \\
(\%)\end{array}$} \\
\hline & & & & $\mathrm{St}$ & $\mathrm{Sc}$ & Pre & Un & $\mathrm{St}$ & $\mathrm{Sc}$ & $\mathrm{Lg}$ & Un & FW & Oth & \\
\hline \multirow{18}{*}{$\begin{array}{l}\text { Gamma } \\
\text { irradiation }\end{array}$} & \multirow{6}{*}{$\mathrm{V}_{1}$} & Control & $\begin{array}{r}9.89 \\
\pm 0.06^{\mathrm{a}} \\
\end{array}$ & & & & & & & & & & & - \\
\hline & & $100 \mathrm{~Gy}$ & $\begin{array}{r}9.74 \\
\pm 0.14^{\mathrm{a}} \\
\end{array}$ & $\begin{array}{r}0.39 \\
\pm 0.01^{\mathrm{c}} \\
\end{array}$ & - & - & - & $\begin{array}{c}0.16 \\
\pm 0.03^{\mathrm{d}} \\
\end{array}$ & - & - & - & - & - & $\begin{array}{c}0.55 \\
\pm 0.04^{\mathrm{e}} \\
\end{array}$ \\
\hline & & $200 \mathrm{~Gy}$ & $\begin{aligned} & 8.59 \\
& \pm 0.30^{b}\end{aligned}$ & $\begin{aligned} & 0.45 \\
\pm & 0.01^{\mathrm{bc}}\end{aligned}$ & - & - & $\begin{array}{c}0.30 \\
\pm 0.08^{\mathrm{b}} \\
\end{array}$ & $\begin{array}{c}0.37 \\
\pm 0.06^{\mathrm{c}} \\
\end{array}$ & - & - & $\begin{array}{c}0.22 \\
\pm 0.01^{\mathrm{b}} \\
\end{array}$ & - & $\begin{array}{c}0.07 \\
\pm 0.07^{\mathrm{a}} \\
\end{array}$ & $\begin{array}{c}1.43 \\
\pm 0.06^{\mathrm{d}} \\
\end{array}$ \\
\hline & & $300 \mathrm{~Gy}$ & $\begin{array}{r}7.86 \\
\pm 0.06^{\mathrm{c}}\end{array}$ & $\begin{array}{c}0.57 \\
\pm 0.01^{\mathrm{b}}\end{array}$ & - & $\begin{array}{c}0.35 \\
\pm 0.07^{\mathrm{a}}\end{array}$ & $\begin{aligned} & 0.35 \\
\pm & 0.07^{\mathrm{ab}}\end{aligned}$ & $\begin{array}{c}0.49 \\
\pm 0.06^{\mathrm{bc}}\end{array}$ & - & - & $\begin{array}{c}0.35 \\
\pm 0.07^{\mathrm{b}}\end{array}$ & - & $\begin{array}{c}0.07 \\
\pm 0.07^{\mathrm{a}}\end{array}$ & $\begin{array}{c}2.20 \\
\pm 0.03^{\mathrm{c}}\end{array}$ \\
\hline & & $400 \mathrm{~Gy}$ & $\begin{array}{c}6.98 \\
\pm 0.11^{\mathrm{d}}\end{array}$ & $\begin{array}{c}0.60 \\
\pm 0.01^{\mathrm{b}}\end{array}$ & $\begin{array}{c}0.20 \\
\pm 0.01^{\mathrm{a}}\end{array}$ & $\begin{array}{c}0.40 \\
\pm 0.01^{\mathrm{a}}\end{array}$ & $\begin{array}{c}0.53 \\
\pm 0.07^{\mathrm{a}}\end{array}$ & $\begin{aligned} & 0.60 \\
\pm & 0.01^{\mathrm{ab}}\end{aligned}$ & $\begin{array}{c}0.13 \\
\pm 0.06^{\mathrm{a}}\end{array}$ & $\begin{array}{c}0.20 \\
\pm 0.01^{b}\end{array}$ & $\begin{array}{c}0.33 \\
\pm 0.07^{\mathrm{b}}\end{array}$ & $\begin{array}{c}0.20 \\
\pm 0.01^{\mathrm{b}}\end{array}$ & $\begin{array}{c}0.06 \\
\pm 0.06^{\mathrm{a}}\end{array}$ & $\begin{array}{c}3.27 \\
\pm 0.15^{\mathrm{b}}\end{array}$ \\
\hline & & $500 \mathrm{~Gy}$ & $\begin{array}{r}4.95 \\
\pm 0.11^{\mathrm{e}} \\
\end{array}$ & $\begin{array}{r}0.89 \\
\pm 0.01^{\mathrm{a}} \\
\end{array}$ & $\begin{array}{c}0.17 \\
\pm 0.01^{\mathrm{b}} \\
\end{array}$ & $\begin{array}{c}0.41 \\
\pm 0.04^{\mathrm{a}} \\
\end{array}$ & $\begin{array}{c}0.53 \\
\pm 0.01^{\mathrm{a}} \\
\end{array}$ & $\begin{array}{c}0.71 \\
\pm 0.02^{\mathrm{a}} \\
\end{array}$ & $\begin{array}{c}0.17 \\
\pm 0.01^{\mathrm{a}} \\
\end{array}$ & $\begin{array}{c}0.35 \\
\pm 0.01^{\mathrm{a}} \\
\end{array}$ & $\begin{array}{c}0.59 \\
\pm 0.05^{\mathrm{a}} \\
\end{array}$ & $\begin{array}{c}0.33 \\
\pm 0.02^{\mathrm{a}} \\
\end{array}$ & $\begin{array}{c}0.05 \\
\pm 0.05^{\mathrm{a}} \\
\end{array}$ & $\begin{array}{c}4.25 \\
\pm 0.07^{\mathrm{a}} \\
\end{array}$ \\
\hline & \multirow{6}{*}{ V2 } & Control & $\begin{array}{c}9.72 \\
\pm 0.08^{\mathrm{a}} \\
\end{array}$ & & & & & & & & & & & - \\
\hline & & $100 \mathrm{~Gy}$ & $\begin{array}{c}9.15 \\
\pm 0.08^{\mathrm{b}}\end{array}$ & $\begin{array}{c}0.50 \\
\pm 0.12^{\mathrm{a}} \\
\end{array}$ & - & - & $\begin{array}{c}0.06 \\
\pm 0.06^{\mathrm{d}}\end{array}$ & $\begin{array}{c}0.25 \\
\pm 0.07^{\mathrm{c}} \\
\end{array}$ & - & - & $\begin{array}{c}0.05 \\
\pm 0.05^{\mathrm{c}}\end{array}$ & - & - & $\begin{array}{c}0.89 \\
\pm 0.18^{\mathrm{e}} \\
\end{array}$ \\
\hline & & $200 \mathrm{~Gy}$ & $\begin{array}{c}8.53 \\
\pm 0.08^{\mathrm{c}} \\
\end{array}$ & $\begin{array}{c}0.52 \\
\pm 0.09^{\mathrm{a}} \\
\end{array}$ & - & - & $\begin{array}{c}0.22 \\
\pm 0.0 c^{\mathrm{cd}} \\
\end{array}$ & $\begin{array}{c}0.44 \\
\pm 0.01^{\mathrm{ab}} \\
\end{array}$ & - & - & $\begin{array}{c}0.30 \\
\pm 0.09^{\mathrm{b}} \\
\end{array}$ & - & $\begin{array}{c}0.07 \\
\pm 0.07^{\mathrm{a}} \\
\end{array}$ & $\begin{array}{c}1.56 \\
\pm 0.18^{\mathrm{d}} \\
\end{array}$ \\
\hline & & $300 \mathrm{~Gy}$ & $\begin{array}{c}7.61 \\
\pm 0.07^{\mathrm{d}} \\
\end{array}$ & $\begin{array}{c}0.71 \\
\pm 0.07^{\mathrm{a}}\end{array}$ & $\begin{array}{c}0.21 \\
\pm 0.01^{\mathrm{a}}\end{array}$ & $\begin{array}{c}0.21 \\
\pm 0.01^{\mathrm{c}} \\
\end{array}$ & $\begin{array}{c}0.35 \\
\pm 0.07^{\mathrm{bc}}\end{array}$ & $\begin{array}{c}0.57 \\
\pm 0.07^{\mathrm{a}} \\
\end{array}$ & $\begin{array}{c}0.07 \\
\pm 0.07^{\mathrm{ab}}\end{array}$ & - & $\begin{array}{r}0.42 \\
\pm 0.01^{\mathrm{ab}} \\
\end{array}$ & - & $\begin{array}{c}0.07 \\
\pm 0.07^{\mathrm{a}}\end{array}$ & $\begin{array}{c}2.63 \\
\pm 0.07 \mathrm{c}\end{array}$ \\
\hline & & $400 \mathrm{~Gy}$ & $\begin{array}{c}6.43 \\
\pm 0.09^{\mathrm{e}}\end{array}$ & $\begin{array}{c}0.70 \\
\pm 0.14^{\mathrm{a}}\end{array}$ & $\begin{array}{c}0.25 \\
\pm 0.06^{\mathrm{a}}\end{array}$ & $\begin{array}{c}0.38 \\
\pm 0.01^{\mathrm{b}}\end{array}$ & $\begin{array}{c}0.50 \\
\pm 0.05^{\mathrm{ab}}\end{array}$ & $\begin{array}{c}0.63 \\
\pm 0.08^{\mathrm{a}}\end{array}$ & $\begin{array}{c}0.12 \\
\pm 0.06^{\mathrm{ab}}\end{array}$ & $\begin{array}{c}0.25 \\
\pm 0.07^{\mathrm{b}}\end{array}$ & $\begin{array}{c}0.44 \\
\pm 0.05^{\mathrm{ab}}\end{array}$ & $\begin{array}{c}0.18 \\
\pm 0.01^{\mathrm{b}}\end{array}$ & $\begin{array}{c}0.12 \\
\pm 0.06^{\mathrm{a}}\end{array}$ & $\begin{array}{c}3.59 \\
\pm 0.15^{\mathrm{b}}\end{array}$ \\
\hline & & $500 \mathrm{~Gy}$ & $\begin{array}{c}4.72 \\
\pm 0.10^{\mathrm{f}}\end{array}$ & $\begin{array}{c}0.74 \\
\pm 0.06^{\mathrm{a}} \\
\end{array}$ & $\begin{array}{c}0.22 \\
\pm 0.05^{\mathrm{a}}\end{array}$ & $\begin{array}{c}0.51 \pm 0.0 \\
1^{\mathrm{a}}\end{array}$ & $\begin{array}{c}0.63 \\
\pm 0.06^{\mathrm{a}}\end{array}$ & $\begin{array}{c}0.69 \\
\pm 0.10^{\mathrm{a}}\end{array}$ & $\begin{array}{c}0.23 \\
\pm 0.06^{\mathrm{a}}\end{array}$ & $\begin{array}{c}0.4 \\
0 \pm 0.06^{\mathrm{a}}\end{array}$ & $\begin{array}{c}0.51 \\
\pm 0.01^{\mathrm{a}}\end{array}$ & $\begin{array}{c}0.34 \\
\pm 0.01^{\mathrm{a}}\end{array}$ & $\begin{array}{c}0.11 \\
\pm 0.11^{\mathrm{a}}\end{array}$ & $\begin{array}{c}4.4 \\
0 \pm 0.21^{\mathrm{a}}\end{array}$ \\
\hline & \multirow{6}{*}{ V3 } & Control & $\begin{array}{c}9.54 \\
\pm 0.13^{\mathrm{a}} \\
\end{array}$ & & & & & & & & & & & - \\
\hline & & $100 \mathrm{~Gy}$ & $\begin{array}{c}9.04 \\
\pm 0.08^{\mathrm{b}} \\
\end{array}$ & $\begin{array}{c}0.37 \\
\pm 0.01^{\mathrm{c}} \\
\end{array}$ & - & - & $\begin{array}{c}0.11 \\
\pm 0.05^{\mathrm{c}} \\
\end{array}$ & $\begin{array}{c}0.31 \\
\pm 0.07^{\mathrm{c}} \\
\end{array}$ & - & - & $\begin{array}{c}0.18 \\
\pm 0.10^{\mathrm{b}}\end{array}$ & - & - & $\begin{array}{c}0.98 \\
\pm 0.03^{\text {e }} \\
\end{array}$ \\
\hline & & $200 \mathrm{~Gy}$ & $\begin{array}{c}8.15 \\
\pm 0.08^{\mathrm{c}}\end{array}$ & $\begin{array}{c}0.56 \\
\pm 0.05^{\mathrm{bc}}\end{array}$ & - & - & $\begin{array}{c}0.36 \\
\pm 0.08^{\mathrm{ab}}\end{array}$ & $\begin{array}{c}0.43 \\
\pm 0.01^{\text {bc }}\end{array}$ & - & - & $\begin{array}{c}0.21 \\
\pm 0.01^{\mathrm{b}}\end{array}$ & - & $\begin{array}{c}0.07 \\
\pm 0.07^{\mathrm{a}}\end{array}$ & $\begin{array}{c}1.64 \\
\pm 0.12^{\mathrm{d}} \\
\end{array}$ \\
\hline & & $300 \mathrm{~Gy}$ & $\begin{array}{r}7.46 \\
\pm 0.10^{\mathrm{d}} \\
\end{array}$ & $\begin{array}{c}0.91 \\
\pm 0.07^{\mathrm{a}}\end{array}$ & $\begin{array}{c}0.13 \\
\pm 0.06^{\mathrm{ab}}\end{array}$ & $\begin{array}{c}0.14 \\
\pm 0.70^{\mathrm{b}}\end{array}$ & $\begin{array}{c}0.34 \\
\pm 0.06^{\mathrm{b}}\end{array}$ & $\begin{array}{c}0.70 \\
\pm 0.14^{\mathrm{ab}}\end{array}$ & $\begin{array}{c}0.07 \\
\pm 0.07^{\mathrm{ab}}\end{array}$ & - & $\begin{array}{c}0.27 \\
\pm 0.06^{\mathrm{b}}\end{array}$ & - & $\begin{array}{c}0.13 \\
\pm 0.13^{\mathrm{a}}\end{array}$ & $\begin{array}{c}2.72 \\
\pm 0.02^{\mathrm{c}}\end{array}$ \\
\hline & & $400 \mathrm{~Gy}$ & $\begin{array}{c}6.03 \\
\pm 0.08^{\mathrm{e}} \\
\end{array}$ & $\begin{array}{c}0.59 \\
\pm 0.04^{\mathrm{b}} \\
\end{array}$ & $\begin{array}{r}0.11 \\
\pm 0.05^{\mathrm{ab}} \\
\end{array}$ & $\begin{array}{c}0.4 \\
1 \pm 0.07^{\mathrm{a}}\end{array}$ & $\begin{array}{c}0.53 \\
\pm 0.01^{\text {ab }} \\
\end{array}$ & $\begin{array}{c}0.60 \\
\pm 0.07^{\mathrm{ab}}\end{array}$ & $\begin{array}{c}0.17 \\
\pm 0.09^{\mathrm{ab}}\end{array}$ & $\begin{array}{c}0.35 \\
\pm 0.01^{\mathrm{a}} \\
\end{array}$ & $\begin{array}{c}0.53 \\
\pm 0.01^{\mathrm{a}} \\
\end{array}$ & $\begin{array}{c}0.29 \\
\pm 0.06^{\mathrm{a}} \\
\end{array}$ & $\begin{array}{c}0.05 \\
\pm 0.05^{\mathrm{a}} \\
\end{array}$ & $\begin{array}{c}3.67 \\
\pm 0.03^{\mathrm{b}} \\
\end{array}$ \\
\hline & & $500 \mathrm{~Gy}$ & $\begin{array}{c}4.62 \\
\pm 0.08^{\mathrm{f}}\end{array}$ & $\begin{array}{c}0.84 \\
\pm 0.10^{\mathrm{a}}\end{array}$ & $\begin{array}{c}0.22 \\
\pm 0.05^{\mathrm{a}}\end{array}$ & $\begin{array}{c}0.50 \\
\pm 0.01^{\mathrm{a}}\end{array}$ & $\begin{array}{c}0.56 \\
\pm 0.06^{\mathrm{a}}\end{array}$ & $\begin{array}{c}0.78 \\
\pm 0.06^{\mathrm{a}}\end{array}$ & $\begin{array}{c}0.24 \\
\pm 0.05^{\mathrm{a}}\end{array}$ & $\begin{array}{c}0.33 \\
\pm 0.01^{\mathrm{b}}\end{array}$ & $\begin{array}{c}0.56 \\
\pm 0.06^{\mathrm{a}}\end{array}$ & $\begin{array}{c}0.33 \\
\pm 0.01^{\mathrm{a}}\end{array}$ & $\begin{array}{c}0.11 \\
\pm 0.11^{\mathrm{a}}\end{array}$ & $\begin{array}{c}4.50 \\
\pm 0.19^{\mathrm{a}}\end{array}$ \\
\hline
\end{tabular}

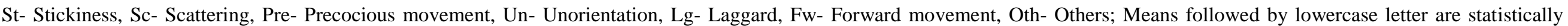
significant at $p<0.05$ in Duncan's Multiple Range Test. 

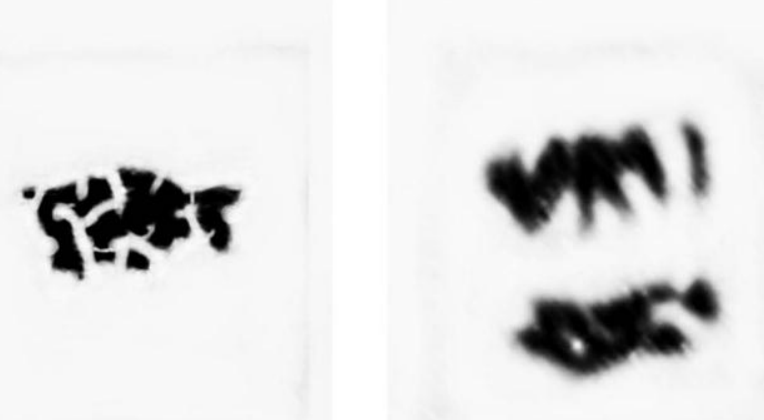

B

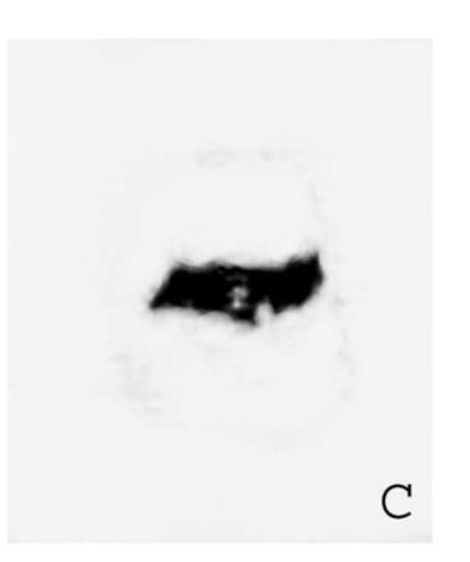

A

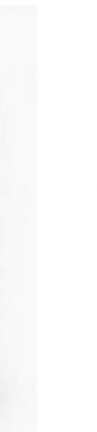

D

E
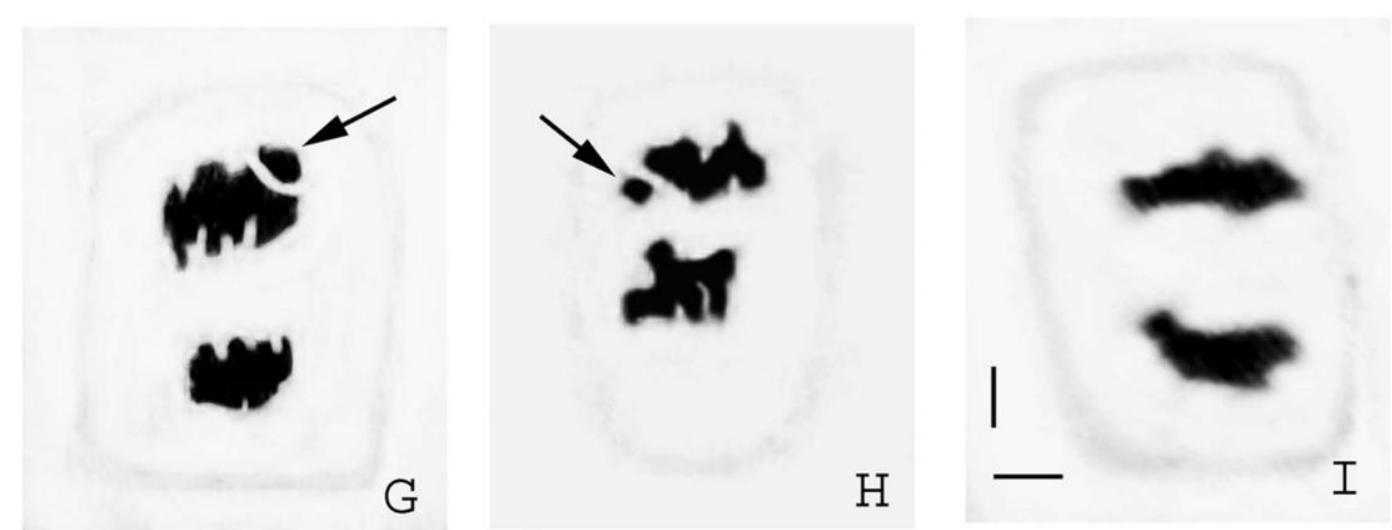

Fig. 2. Cytological plate showing different chromosomal abnormalities.

A: Normal metaphase $(2 n=22)$, B: Normal anaphase $(22: 22$ separation), C: Stickiness of chromosomes at metaphase, D: Unoriented with precocious chromosomes at metaphase, E: Unoriented metaphase, F: Scattering at metaphase, G: Forward chromosomes at anaphase, H: Laggard chromosomes at anaphase, I: Stickiness at anaphase. Scale bar: length $6.73 \mu \mathrm{m}$; width $9.68 \mu \mathrm{m}$. Arrows show; on D, unorientation with precocious chromosome, on $\mathrm{G}$, one forward chromosome, on $\mathrm{H}$, one laggard chromosome.

reported that the germination percentage of the variety Arkajay was found to be highest at all doses.

Influence of gamma irradiation on AMI (Active Mitotic Index) The effect of gamma irradiation on the plant was in a dose dependent manner. A highly significant decrease in $\mathrm{AMI} \%$ compared to the control was evident at all doses. The mitotic actively dividing cells of the root meristems zone of the plant variety Arkajay executed highest value of AMI\% at all doses; ranging from $9.74 \pm 0.14$ at 100 Gy to $4.95 \pm 0.11$ at 500 Gy respectively and the value of the AMI\% in plant variety RP-08-31 was scored from $9.04 \pm 0.08$ at 100 Gy to $4.62 \pm 0.08$ at $500 \mathrm{~Gy}$, which was the lowest AMI\% among all the three varieties 


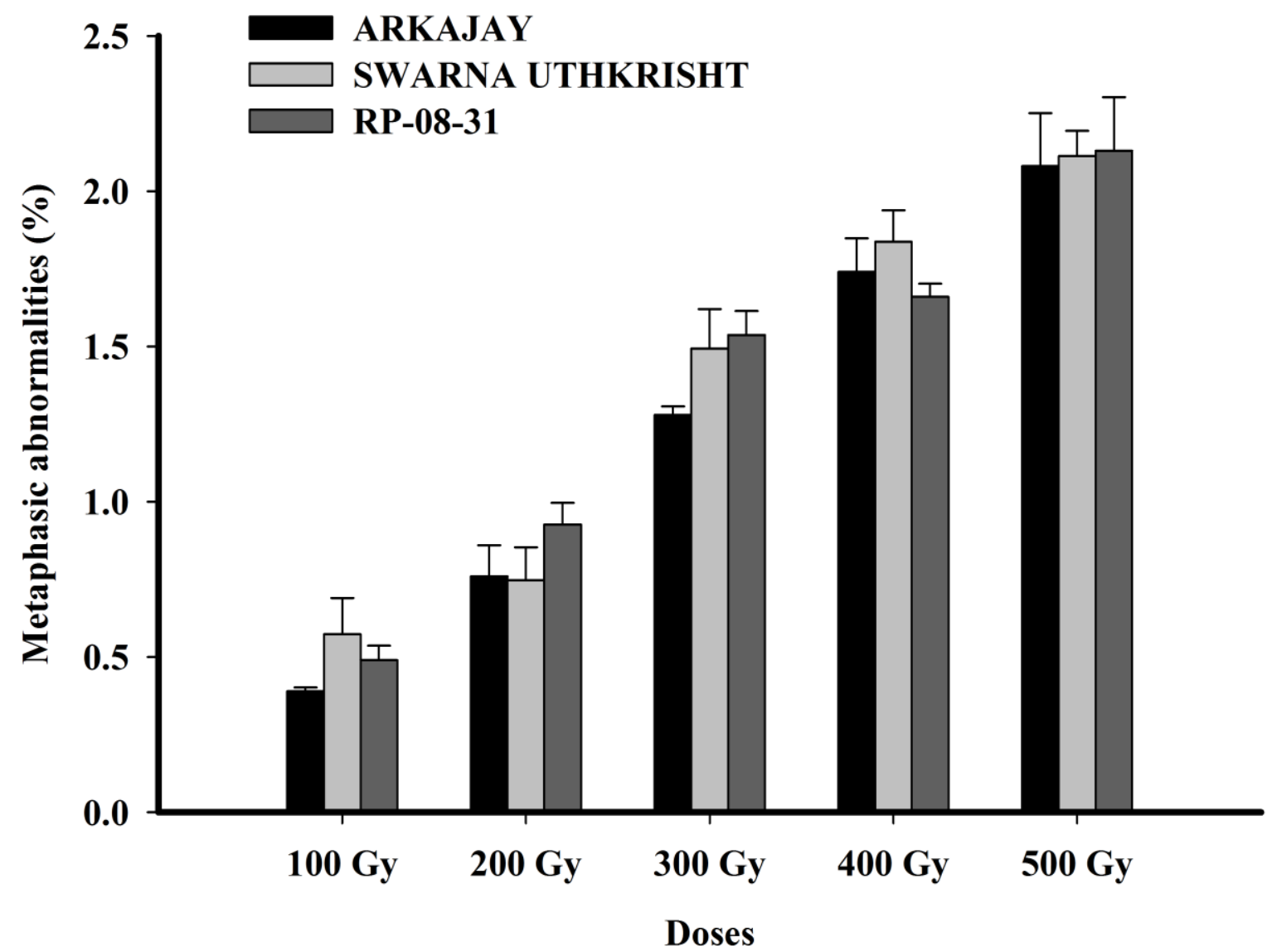

Fig. 3. Comparative account of metaphasic abnormalities induced by gamma irradiation in three varieties of Dolichos labab L.

at all doses. AMI\% of variety Swarna utkrishit 9.15 \pm 0.08 to $4.72 \pm 0.10$ was in between of the AMI\% of these two. The expression of values of AMI\% inferred mitotic activity of the meristematic cells was greater in the plant variety Arkajay then in Swarna utkrishit and the least in the case of plant variety RP-08-31. The values of AMI\% at doses of $100 \mathrm{~Gy}$ and $200 \mathrm{~Gy}$ were slightly decreased, while 300 Gy onwards, a major reduction in AMI\% was recorded. A vast fall off in the AMI\% value at $500 \mathrm{~Gy}$ doses was evidenced, which concluded lethality of this dose.

Influence on chromosomal structure Percentage of various chromosome abnormalities induced by gamma irradiation in the abnormal cells of root meristem of plant varieties is documented in Table 1. At highest dose, the percentage of these abnormalities was highest compared to lower doses of gamma rays. The plant variety RP-08-31 showed highest $\mathrm{TAB} \%$ i.e. $0.98 \pm 0.03$ to $4.50 \pm 0.19$. In other two varieties, the TAB\% increased from $0.55 \pm 0.04$ to $4.25 \pm 0.07$ in case of Arkajay whereas an increment from $0.89 \pm 0.18$ to $4.40 \pm 0.21$ was found in Swarna Utkrishit variety of Dolichos lablab L. Fig. 2 illustrates various types of chromosomal abnormalities triggered by gamma irradiation. Fig. 2A shows normal metaphasic stage $(2 n=22)$ of mitosis (Fig. 2B) represents normal anaphasic configuration of the division phase, in which chromosomes. Fig. 2C showed about prominent abnormalities at metaphase i.e. stickiness of chromosomes, unorientation of metaphasic stage (Fig. 2E) and scattering of chromosomes (Fig. 2F). Fig. 2D showed the unoriented Metaphasic abnormality with two precocious chromosomes. At Anaphase stage of cell division (Fig. 2G) represent one forward movement of chromosome whereas (Fig. 2H) display the one Laggard chromosome. (Fig. 2I) shows stickiness of chromosomes at Anaphase stage of mitotic cell division. The stickiness of chromosomes was also a dominant abnormality at anaphase stage. Fig. 3 and Fig. 4 represents the comparison of the Metaphasic and anaphase chromosome abnormalities observed in the three varieties of the plant $D$. lablab. From Fig. 3, it is clear that at the dose of 100 and 400 Gy the plant variety Swarna uthkrishit have highest Metaphase abnormality compared to other two plant varieties, whereas at doses of 200, 300 and 500 Gys., the plant variety RP-08-31 showed highest chromosomal abnormality. In (Fig. 4), at the dose of 200 Gy Swarna uthkrishit variety represents highest anaphase abnormalities. Percentage of various chromosomal ab- 


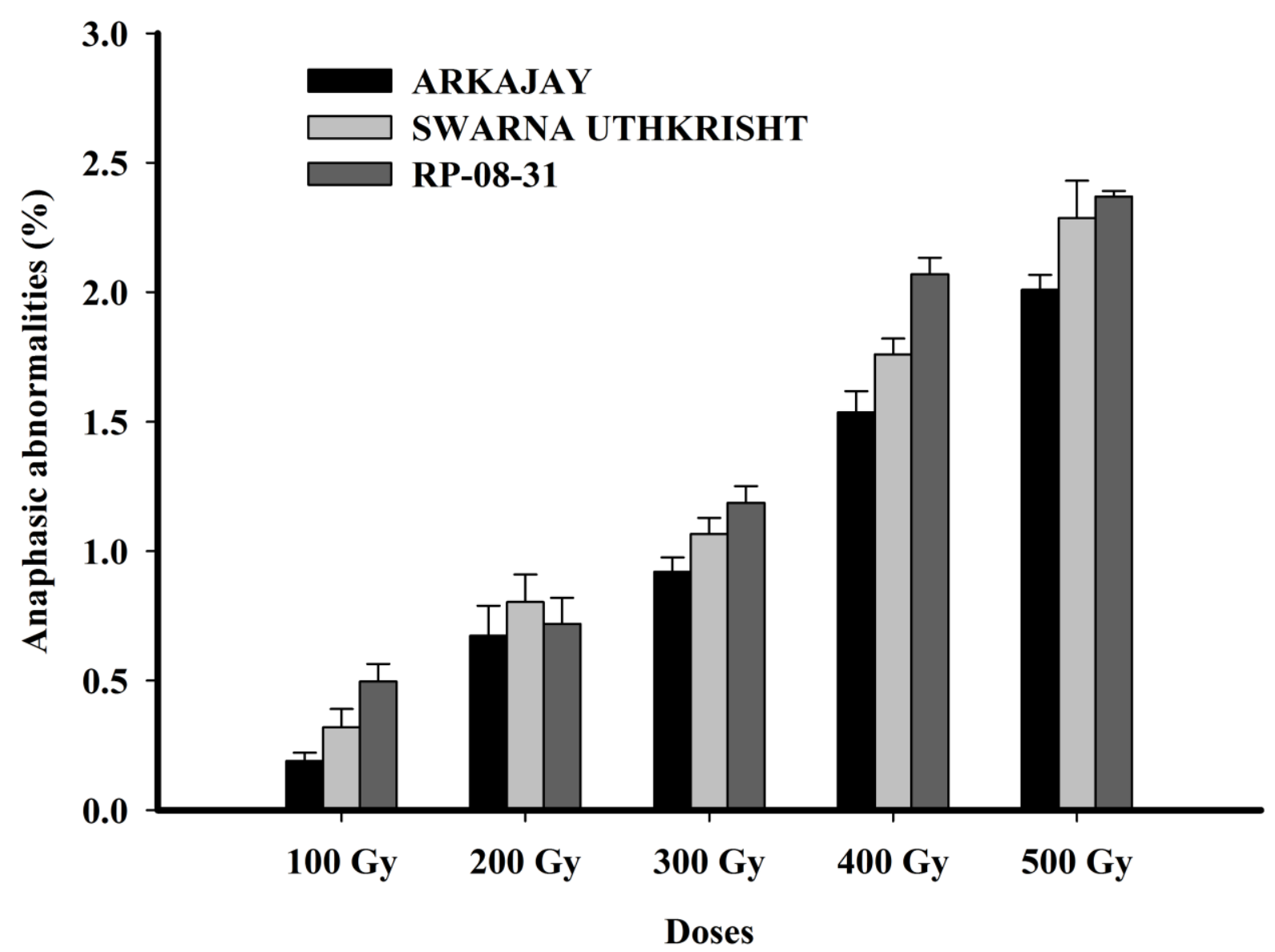

Fig. 4. Comparative account of anaphasic abnormalities induced by gamma irradiation in three varieties of Dolichos labab L.

normalities induced by gamma irradiation in the abnormal cells of the root meristems of plant varieties is documented in Table 1. At highest dose, the percentage of these abnormalities was highest compared to the lower doses of gamma rays studied. The plant variety RP-08-31 showed the highest $\mathrm{TAB} \%$, i.e. $0.98 \pm 0.03$ to $4.50 \pm 0.19$. In the other two varieties, the TAB\% increased from $0.55 \pm 0.04$ to $4.25 \pm 0.07$ in case of Arkajay whereas an increment from $0.89 \pm 0.18$ to $4.40 \pm 0.21$ was found in $S$. utkrishit a variety of $D$. lablab. Fig. 2 illustrates various types of chromosomal abnormalities triggered by gamma irradiation. Fig. 2A showed normal metaphase stage $(2 n=$ 22) of mitosis (Fig. 2B) represents normal anaphase configuration of the division phase, in the chromosomes. Fig. 2C showed about prominent abnormalities at metaphase i.e. stickiness of chromosomes, unorientation of metaphase stage (Fig. 2E) and scattering of chromosomes (Fig. 2F). Fig. 2D showed the unoriented metaphase abnormality with two precocious chromosomes. At anaphase stage of cell division (Fig. 2G) represent one forward movement of chromosome whereas (Fig. 2H) display one lagging chromosome. Fig. 2I shows stickiness of chromosomes at anaphase stage of mitotic cell division. The stickiness of chromosomes was also a dominant abnormality at anaphase stage. Figs. 3 and 4 represent the comparison of the metaphase and anaphase chromosome abnormalities observed in three varieties of D. lablab. From Fig. 3, it is clear that at the dose of 100 and 400 Gys. The plant variety Swarna uthkrishit have highest metaphase abnormality compared to other two plant varieties, whereas at doses at 200, 300 and 500 Gys, the plant variety RP-08-31shows highest chromosomal abnormality. In Fig. 4, at the dose of 200 Gy S. uthkrishit variety represents highest anaphasic abnormalities.

\section{Discussion}

Mechanism of Gamma Rays Gamma rays pointed to the water molecule, and produces ionized water molecules $\left(\mathrm{H}_{2} \mathrm{O}^{\cdot+}\right)$, the radicals $\mathrm{H}^{\cdot}$ and ${ }^{\circ} \mathrm{OH}$ and secondary reactive oxygen species (ROS) as $\mathrm{H}^{\cdot} \mathrm{H}_{2} \mathrm{O}_{2}, \mathrm{O}_{2}{ }^{\prime}$ (Tubiana 2008; Lee et al. 2009).These radicals might be translocated through the cell sap and effect the mitotic actively dividing cells of root meristem and also fluctuate the germination frequency of the seeds.

Effects of Doses Considering about the effect of gamma radiation on biological tissues it is observed that lower doses stimulates the cell division and higher-doses inhibits the cell division due to free radicals and DNA system damage (Zaka et al. 2004). The beneficial effects 
of low doses of gamma irradiation accomplished with the phenomenon of Hormesis (Luckey 1980; Sagan 1987; Planel et al. 1987; Korystov and Narimanov 1997).

Germination With respect to germination of the seeds of different plants, Borzouei et al. (2010) in Triticum aestivum L. observed that gamma irradiation stimulated germination of the seeds. Such stimulatory effects of lower doses to seed germination has been reported in majority of other legumes such as chickpea (Melki and Salami 2008) and soybeans (Mudibu et al. 2011).

Effects on Mitotic Indices Mitotic index measures the proportion of cells in the M-phase of the cell cycle and its inhibition could be interpreted as cellular death (Rojas et al. 1993). Reduction in the mitotic activity could be due to inhibition of DNA synthesis or a blocking in the G2 phase of the cell cycle, preventing the cell from entering mitosis (Van't Hof 1968; Schneiderman et al. 1971; Beu et al. 1976; Sudhakar et al. 2001). When cells are exposed to radiation, DNA sometimes breaks, and the broken ends may rejoin in different patterns from their original arrangement. It may be visualized at mitosis when cells divide; these breaks resulted in chromosomal aberrations (radefx).

Effects on Chromosomal Morphology The study of radiation induced in chromosomal aberrations in certain plants has been done by several workers such as: in Lathyrus sativum (Tripathi and Kumar 2011), in Vicia faba (Kihlman and Anderson 1984) and in Vigna mungo (Goyal and Khan 2009). Swierenga et al. (1991) suggested that chromosomal aberrations (CA) are extremely valuable for study of variations created by mutagens. Most of the CA observed in cells are lethal, but there are many corresponding aberrations that are viable and can cause genetic effects, either somatic or reproductive (Gadano et al. 2002). Chromosome malsegregation and defects in chromatid separation, bridge formation, chromosome exchange, chromosome breakage and loss, or the loss of chromosome fragments are observed by many researchers (Chenal et al. 2006; Geraskin et al. 2005). These numerous abnormalities generate acentric fragments that are excluded during the late-stages of mitosis and produce micronuclei that reflect these aberrations (Zaka et al. 2002a). Dhanavel et al. (2012) reported increased chromosomal abnormalities in the Co7 variety of cowpea with increasing dose of $\gamma$-radiation.

Beadle (1932) reported chromosome stickiness in maize for the first time and attributed such irregularity to a mutation caused by a recessive gene called sticky ( $s t)$. Levan (1945) and Liu et al. (1995) have both reported severe cytological abnormalities in the dividing cells of onion (Allium cepa) roots resulting from chromosomal stickiness. The scattering of chromosomes appeared due to loss of microtubules of spindle fibres (Heaps et al. 1982; Salam et al. 1993). Kumar and Rai (2007) reported that unorientation at metaphase and scattering of chromosomes may be due to inhibition of spindle formation or destruction of spindle formed.

Precocious movement of chromosomes was observed when doses of mutagens increased. It might have been caused by the early terminalization, stickiness of chromosomes or because of the rest during anaphase (Permjit and Grover 1985).

Lagging chromosomes may be due to abnormal spindle formation and as a result spindle fibres fail to carry the respective chromosomes to the polar region and resultantly lagging chromosome appeared (Tarar and Dyansagar 1980). Lagging chromosomes occur because of improper movement of chromosomes during anaphase separation (Soheir et al. 1989).

\section{ConClusion}

From the above cytological analysis, it has been concluded that gamma rays induced various chromosomal aberrations, which could be desirable in enhancing agronomic traits in the highly proteinaceous plant Dolichos lablab L. This study also assisted in selection of best variety of the plant i.e. Arkajay variety for further experimental work on the basis of the germination percentage and mitotic behaviour of plant. From the experimental finding it has been confirmed that above mentioned research work could be further analysed at meiotic level to generate elite genotype of the plant Dolichos lablab L. var. Arkajay.

ACKNOWLEDGEMENTS. The authors are very thankful to Indian Institute of Horticultural Research (IIHR) and Indian Council of Agricultural Research (ICAR) for providing inbred lines of seeds of Dolichos lablab L. The authors also express their gratitude to the laboratory members for providing suitable guidance and support.

\section{Literature Cited}

Ahirwar, R. 2013. Gamma radiation induced chromosomal aberrations at mitosis in Allium cepa L. International Journal of Science and Research (IJSR) 4(4): 855-858.

Beadle, G. W. 1932. A gene in Zea mays for failure of cytokinesis during meiosis. Cytologia 3: p.142-155.

Beu, S., Schwarz, O. and Hughes, K. W. 1976. Studies of the herbicide Paraquat I. Effects on cell cycle and DNA synthesis in Vicia faba. Can. Journ. Genet. Cytol. 18: 93-99.

Bhogireddy, N., Vamsi Krishna, A. N., Ramesh, B., Pradeep, K., Reddy, O. V. S., Gaddaguti, V., Raj Kumar, K., Pola, P. K. and Venkataraman, B. 2013. Anti-inflammatory and antidiabetic activities with their other ethno-medicinal properties of the plants. Journ. Med. Pl. Stud. 1(5): 87-96.

Borzouei, A., Kafi, M., Khazaei, H., Naseriyan, B. and Majdabadi, A. 2010. Effects of gamma radiation on germination and physiological aspects of wheat (Triticum aestivum L.) seedlings. Pak. Journ. Bot. 42(4): 2281-2290.

Chenal, C., Zaka, R., Legué, F. and Misset, M. T. 2006. Effects of low-dose irradiation on two plant models: Stipa capillata and Pisum sativum. Int. Journ. Low Radiat. 3: 234-240.

Dhanavel, D., Gnanamurthy, S. and Girija, M. 2012. Effect of 
gamma rays on induced chromosomal variation in cowpea Vigna unguiculata (L.). Walp. Int. Journ. Curr. Sci 12: 245250.

Eroglu, Y., Eroglu, H. E., and Ilbas, A. I. 2007. Gamma Ray Reduces Mitotic Index in Embryonic Roots of Hordeum vulgare L. Advances in Biological Research 1 (1-2): 26-28.

Gadano, A., Gurni, A., Lo'pez, P., Ferraro, G. and Carballo, M. 2002. In vitro genotoxic evaluation of the medicinal plant Chenopodium ambrosioides L. Journ. Ethnopharmacology 81(1): 11-16.

Geraskin, S. A., Kim, J. K., Oudalova, A. A., Vasiliyev, D. V., Dikareva, N. S., Zimin, V. L. and Dikarev, V. G. 2005. Biomonitoring the genotoxicity of populations of Scots pine in the vicinity of a radioactive waste storage facility. Mutat. Res. 583: 55-66.

Goyal, S. and Khan, S. A. 2009. Comparative Study of Chromosomal Aberrations in Vigna mungo induced by ethylmethane sulphonate and hydrazine hydrate. Thai. Jorn. Agri. Sci. 42: 177-182

Grodsinsky, D. M., Sokoln, N. V. and Sprochinsky, B. V. 2001. How does low dose chronic irradiation under the condition of $10 \mathrm{~km}$ Chernobyl exclusion zone influence on processes of seed aging. In: Abstract of Proc. of Int. Conf. fifteen years after the Chernobyl Accident, Kiev Ukraine 2: 117.

Heaps, P., Timothy, J. D. and Spurck, P. 1982. Studies on the kinetochore function in mitosis. Effect of colchicines and cytochalasin on mitosis in diatom, Hantzschia amphioxys. European Journ Cell Biol. 28: 77-82.

Kihlman, B. A. 1975. Root tips of Vicia faba for the study of the induction of chromosomal aberrations. Mutat. Res. 31: 401-412.

Kihlman, B. A. and Anderson, H. C. 1984. Root tips of Vicia faba for the study of the induction of chromosomal aberrations and sister chromatid exchanges. Handbook of Mutagenicity test procedures. Publisher Elsevier Science 2: 531-554.

Korystov, Y. N. and Narimanov, A. A. 1997. Low doses of ionizing radiation and hydrogen peroxidase stimulate plant growth. Biologia (Bratislava) 52: 121-124.

Kovács, E. and Keresztes, Á. 2002. Effect of gamma and UV-B/ $\mathrm{C}$ radiation on plant cells. Micron 33: 199-210.

Kumar, G. and Dwivedi, S. 2014. Impact of gamma irradiation on growth response of Crotalaria Juncea L. Intl. Jour. Agri. Crop Sci. 7 (11): 870-875.

Kumar, G. and Rai, P. K. 2007 EMS induced karyomorphological variations in Maize Zea mays L. inbreds. Turk. Journ. Biol. 31: 187-195.

Lee, M. H., Moon, Y. R., Chung, B. Y., Kim, J. S., Lee, K. S., Cho, J. Y. and Kim, J. H. 2009. Practical use of chemical probes for reactive oxygen species produced in biological systems by gamma irradiation. Radiat. Phys. Chem. 78: 323-327.

Levan, A. 1945. Cytological reactions induced by inorganic salt solutions. Nature 156: 751-752.

Liu, D., Jiang, W. and Zhai, L. 1995. Evaluation of metal ion toxicity on root tip cells by the Allium test. Israel J Plant Sci. 43: $125-133$.

Luckey, T. D. 1980. Hormesis with ionizing radiation. Boca
Raton Florida: CRC Press

Marcu, D., Damian, G., Cosma and Cristea, V. 2013. Gamma radiation effects on seed germination, growth and pigment content, and ESR study of induced free radicals in maize Zea mays. Journ. Biol. Phys. 39: 625-634.

Melki, M. and Salami, D. 2008. Studies the effects of low dose of gamma rays on the behavior of Chickpea under various conditions. Pakistan Journ. Biol. Sci. 11(19): 2326-2330.

Mudibu, J., Nkongolo, K. K., Smith, M. and Kalonji-Mbuyi, A. 2011. Genetic analysis of a soybean genetic pool using ISSR marker: Effect of gamma radiation on genetic variability. Int. Journ. Plant Breed. Genet. 5: 235-245.

Oladosu, Y., Rafii, M. Y., Abdullah, N., Hussin, G., Ramli, A., Rahim, H. A., Miah, G. and Usman, M. 2016. Principle and application of plant mutagenesis in crop improvement: a review Biotechnology \& Biotechnological Equipment 30(1): $1-16$.

Permjit, K. and Grover, I. S. 1985. Cytological effects of some organophosphorous pesticides II. Mitotic effects. Cytologia 50: 199-211.

Planel, H., Soleilhavoup, J. P., Tixador, A., Richoilley, G., Conter, A., Croute, F., Caratero, C. and Gaubin, Y. R. 1987. Influence on cell proliferation of background radiation or exposure to very low chronic gamma-radiation. Health Phys. 52: 571-578.

Priya, S. and Jenifer, S. 2014 Antibacterial activity of leaf and flower extract of Lablab purpureus against clinical isolates of Staphylococcus aureus. Journ. Drug Design \& Discov. 1 (3):1-3.

Rojas, E., Herrera, L. A., Sordo, M., Gonsebatt, M. E., Montero, R., Rodriguez, R. and Ostrosky-Wegman, P. 1993. Mitotic index and cell proliferation kinetics for identification of antineoplastic activity. Anticancer Drugs 46: 637-640.

Sagan, L. A. 1987. What is hormesis and why haven't we heard it before? Health Phys. 52: 521-525.

Salam, A. Z., El-abdin., Hussain Ebtissam, H. A., Hanaiya, El-ltriby., Anwar, W. A. and Mansour, S. A. 1993. The mutagenicity of gammaxene (Paraquat) on different eukaryotic systems. Mutat. Res. 319: 89-101.

Schneiderman, M. H., Dewey, W. C. and Highfield, D. P. 1971. Inhibition of DNA synthesis in synchronized Chinese hamster cell treated in G1 with cycloheleximide. Exp. Cell Res. 67: 147-155.

Singh, B. and Datta, P. S. 2010. Gamma irradiation to improve plant vigor, grain development and yield attributes in wheat. Radiat. Phys. Chem. 79: 139-143

Soheir, E., Antointte, H. and Atif, H. 1989. Cytological effects of herbicide garlon-4 on root mitosis of Allium cepa. Cytologia 54: 465-472.

Sudhakar, R. Gowda, N. and Venu, G. 2001. Mitotic abnormalities induced by silk Dyeing Industry Effluents in the cells of Allium cepa. Cytologia 66: 235-239.

Swierenga, S. H. H., Heddle, J. A., Sigal, E. A., Gilman, J. P. W., Brillinger, R. L., Douglas, G. R. and Nestmann, E. R. 1991. Recommended protocols based on a survey of current practice in genotoxicity testing laboratories, IV. Chromosome aberrations and Sister-chromatid exchange in Chinese hamster ovary, V79 Chinese hamster lung and human 
lymphocyte cultures. Mutation Res. 246: 301-322.

Tarar, J. L. and Dyansagar, V. R. 1980. Effect of gamma rays and EMS on growth and branching in Turneria ulmifolia L. Journ. Cytol. Genet. 14: 118-124.

Tripathi, R. and Kumar, G. 2011. Comparative effect of aging and gamma irradiation on the somatic cells of Lathyrus sativum L. Central Europ. Agric. 11: 437-442.

Tubiana, M. 2008. Radiobiologie. Herman, Paris.

Van't Hof, J. 1968. The action of IAA and Kinetin on the mitotic cycle of proliferative and stationary phase excised root meristem. Exp. Cell Res. 51: 167.

Verma, R. C. and Chandel, S. 1994. Annual Chrysanthemum: A New and Novel Material for the Study of Radiation Induced
Chromosomal Aberrations at Mitosis. Cytologia 59: 339-343. www.rerf.jp/radefx/late_e/chromoab.html, 2007.

Zaka, R. Chenal, C. and Misset, M. T. 2002a. Study of external low irradiation dose effects on induction of chromosome aberrations in Pisum sativum root tip meristem. Mutat. Res. 517: 87-99.

Zaka, R., Chenal, C. and Misset, M. T. 2004. Effects of low doses of short term gamma irradiation on growth and development through two generations of Pisum sativam. Science of the Total Environ. 320: 121-129. 